\title{
Comparison Between Oil-Mist and Oil-Jet Lubrication of High-Speed, Small-Bore, Angular-Contact Ball Bearings
}

Stanley I. Pinel

Pinel Engineering, Fullerton, California

Hans R. Signer

Signer Technical Services, Fullerton, California

Erwin V. Zaretsky

Glenn Research Center, Cleveland, Ohio 
Since its founding, NASA has been dedicated to the advancement of aeronautics and space science. The NASA Scientific and Technical Information (STI) Program Office plays a key part in helping NASA maintain this important role.

The NASA STI Program Office is operated by Langley Research Center, the Lead Center for NASA's scientific and technical information. The NASA STI Program Office provides access to the NASA STI Database, the largest collection of aeronautical and space science STI in the world. The Program Office is also NASA's institutional mechanism for disseminating the results of its research and development activities. These results are published by NASA in the NASA STI Report Series, which includes the following report types:

- TECHNICAL PUBLICATION. Reports of completed research or a major significant phase of research that present the results of NASA programs and include extensive data or theoretical analysis. Includes compilations of significant scientific and technical data and information deemed to be of continuing reference value. NASA's counterpart of peerreviewed formal professional papers but has less stringent limitations on manuscript length and extent of graphic presentations.

- TECHNICAL MEMORANDUM. Scientific and technical findings that are preliminary or of specialized interest, e.g., quick release reports, working papers, and bibliographies that contain minimal annotation. Does not contain extensive analysis.

- CONTRACTOR REPORT. Scientific and technical findings by NASA-sponsored contractors and grantees.
- CONFERENCE PUBLICATION. Collected papers from scientific and technical conferences, symposia, seminars, or other meetings sponsored or cosponsored by NASA.

- SPECIAL PUBLICATION. Scientific, technical, or historical information from NASA programs, projects, and missions, often concerned with subjects having substantial public interest.

- TECHNICAL TRANSLATION. Englishlanguage translations of foreign scientific and technical material pertinent to NASA's mission.

Specialized services that complement the STI Program Office's diverse offerings include creating custom thesauri, building customized data bases, organizing and publishing research results ... even providing videos.

For more information about the NASA STI Program Office, see the following:

- Access the NASA STI Program Home Page at http://www.sti.nasa.gov

- E-mail your question via the Internet to help@sti.nasa.gov

- Fax your question to the NASA Access Help Desk at 301-621-0134

- Telephone the NASA Access Help Desk at 301-621-0390

- Write to: NASA Access Help Desk NASA Center for AeroSpace Information 7121 Standard Drive Hanover, MD 21076 
NASA/TM-2001-210462

\section{Comparison Between Oil-Mist and Oil-Jet Lubrication of High-Speed, Small-Bore, Angular-Contact Ball Bearings}

Stanley I. Pinel

Pinel Engineering, Fullerton, California

Hans R. Signer

Signer Technical Services, Fullerton, California

Erwin V. Zaretsky

Glenn Research Center, Cleveland, Ohio

Prepared for the

56th Annual Meeting sponsored by The Society of Tribologists and Lubrication Engineers Orlando, Florida, May 20-24, 2001

National Aeronautics and

Space Administration

Glenn Research Center 
Available from

NASA Center for Aerospace Information 7121 Standard Drive

Hanover, MD 21076
National Technical Information Service 5285 Port Royal Road Springfield, VA 22100

Available electronically at http://gltrs.grc.nasa.gov/GLTRS 


\title{
Comparison Between Oil-Mist and Oil-Jet Lubrication of High-Speed, Small-Bore, Angular-Contact Ball Bearings
}

\author{
Stanley I. Pinel \\ Pinel Engineering \\ Fullerton, California \\ Hans R. Signer \\ Signer Technical Services \\ Fullerton, California \\ Erwin V. Zaretsky \\ National Aeronautics and Space Administration \\ Glenn Research Center \\ Cleveland, Ohio 44135
}

Parametric tests were conducted with an optimized 35-mmbore-angular-contact ball bearing on a high-speed, hightemperature bearing tester. Results from both air-oil mist lubrication and oil-jet lubrication systems used to lubricate the bearing were compared to speeds of $2.5 \times 10^{6} \mathrm{DN}$. The maximum obtainable speed with air-oil mist lubrication is $2.5 \times 10^{6} \mathrm{DN}$. Lower bearing temperatures and higher power losses are obtained with oil-jet lubrication than with air-oil mist lubrication. Bearing power loss is a direct function of oil flow to the bearing and independent of oil delivery system. For a given oil-flow rate, bearing temperature and power loss increase with increases in speed. Bearing life is an inverse function of temperature, the difference in temperature between the individual bearing ring components, and the resultant elastohydrodynamic (EHD) film thicknesses. Bearing life is independent of the oil delivery system except as it affects temperature. Cage slip increased with increases in speed. Cage slip as high as 7 percent was measured and was generally higher with air-oil mist lubrication than with oil-jet lubrication.

\section{INTRODUCTION}

Grease and simple splash lubrication are the lubrication means of preference for most low-speed machinery applications where the bearing speeds are less than $200000 \mathrm{DN}$. ( $D N$ is a rolling-element bearing speed parameter where $D$ represents the bearing bore in millimeters and $N$ the bearing inner-ring speed in rpm.) For aircraft engines, turbomachinery, and drive trains, jet lubrication is used both to lubricate bearings and gears and to control their temperature by removing generated heat. In jet lubrication the placement and number of nozzles, the jet velocity, the lubricant flow rates, and the removal of lubricant from the bearing and immediate vicinity are all important for satisfactory operation, Zaretsky (1).

A more effective and efficient means of lubricating rollingelement bearings is under-race lubrication so that increasing the oil flow decreases the ring temperature. Conventional jet lubrication fails to adequately cool and lubricate the innerrace contact because lubricant is thrown centrifugally outward. While increasing flow rate results in carrying away more heat, it also adds to the heat generated from oil churning, Zaretsky (1).

Ring cooling by oil flow at the exterior ring surfaces has been used for many years for high-speed turbomachinery bearings. To achieve speeds of 3 million $D N$ with angularcontact ball bearings and cylindrical roller bearings, Zaretsky et al. (2) and Signer et al. (3) proposed the concept of "bearing thermal management" as the proper technological approach to high-speed bearing operation. Bearings lubricated through the inner ring passages were also provided with cooling of the external outer ring surfaces. The basis of this concept was the recognition that total and flexible thermal control over the bearing components was essential to achieving a reliable high-speed, highly loaded bearing, Zaretsky (1). 
Both the conventional jet and the under-ring lubrication systems recirculate the oil used as the lubricant. There are rotating machinery applications in which a nonrecirculating lubrication system, which operates with minimum possible oil flow, could be employed advantageously. Weight and cost reduction of the system might be realized. One such lubricating system that has been used commercially for decades is airoil mist lubrication. Oil-mist lubrication systems have been used extensively for industrial applications, high-speed machine spindles, and in limited aerospace applications. Bloch and Shamim (4) describe these oil-mist lubrication systems together with performance data.

Early work by Schuller and Anderson $(5,6)$ studied and determined the effects of minimum oil flow with air-oil mist lubricated, thrust-loaded, 75-mm angular-contact ball bearings to $1.2 \times 10^{6} \mathrm{DN}$ under varying loads, oil-flow rates and temperature. They found that the bearings operated satisfactory at very low oil flows with air-oil mist lubrication using a synthetic diester lubricant (MIL-L-7808). Minimum oil-flow requirements increased with increases in load and speed. They developed for an air-oil mist lubrication system an empirical formula relating minimum oil-flow requirements as a function of load and speed for successful ball bearing operation.

Research performed by Morrison et al. (7) with 45-mm angular-contact ball bearings run to speeds of $135000 \mathrm{DN}$ run with sump lubrication and air-oil mist found that the air-oil mist lubrication system resulted in lower bearing temperatures on the order of 12 to $15^{\circ} \mathrm{C}$ ( 22 to $\left.27^{\circ} \mathrm{F}\right)$. Shamim and Kettleborough $(4,8)$ also compared an air-oil mist lubrication system with a conventional sump lubrication system for 60-mm-bore-angular-contact ball bearings run to speeds of $144000 \mathrm{DN}$. Their results were similar to those of Morrison et al. ( 7 ) where the air-oil mist lubricated bearing ran $10^{\circ} \mathrm{C}\left(18^{\circ} \mathrm{F}\right)$ cooler than the sump lubricated bearing and at a lower power loss.

Rosenlieb (9) performed once-through, air-oil mist lubrication studies with 125-mm-bore-angular-contact ball bearings made from AISI M-50 steel. The lubricants used in his study were two synthetic paraffinic hydrocarbon fluids and a Type II advanced ester fluid. He demonstrated the feasibility of airoil mist lubrication to speeds of $2.5 \times 10^{6} \mathrm{DN}$ at bearing temperatures of $216^{\circ} \mathrm{C}\left(420^{\circ} \mathrm{F}\right)$ for periods of time up to $35 \mathrm{hr}$ at an oil-flow rate as low as $3.7 \times 10^{-3} \mathrm{\ell} / \mathrm{min}$. Increasing the air-oil mist temperature resulted in an equal increase in bearing temperature.

In a follow-on study, Rosenlieb (10) demonstrated that an air-oil mist system along with auxiliary air cooling could provide short-term operation of a $46-\mathrm{mm}$-bore-angularcontact ball bearing to speeds up to $3 \times 10^{6} \mathrm{DN}$ and temperatures up to $264{ }^{\circ} \mathrm{C}\left(505{ }^{\circ} \mathrm{F}\right)$ with flow rates as low as $0.9 \times 10^{-3} \mathrm{\ell} / \mathrm{min}$. However, at speeds greater than $2.5 \times 10^{6} \mathrm{DN}$ bearing cage instability and wear occurred. The cage instability occurred only with oil-mist lubrication and not with oil-jet lubrication. He attributed the cage instability to the reduced oil damping provided by the air-oil mist. The lubricants used in this study were two different Type I esters meeting the MIL-L-7808 specification, a Type II ester meeting the MIL-L-23699 specification, and a polyphenylether. Rosenlieb (10) also ran air-oil mist bearing lubrication endurance tests at $2 \times 10^{6}$ and $2.5 \times 10^{6} \mathrm{DN}$ for 100 and $50 \mathrm{hr}$, respectively.

Jeng and Huang (11) compared the temperature rise of hybrid ceramic and steel 50-mm-bore-angular-contact ball bearings run to $750000 \mathrm{DN}$. For their tests they varied load, speed, airflow rate, and oil quality. Their test results compared well with those of Schuller and Anderson $(5,6)$. Increasing the airflow rate for a constant lubricant flow marginally reduced bearing temperature. Bearing temperature increased with speed and to a lesser extent with load and decreased lubricant flow rate. The hybrid ceramic bearing ran at lower temperatures than the steel bearing by 4 to $8^{\circ} \mathrm{C}\left(7\right.$ to $\left.14^{\circ} \mathrm{F}\right)$. However, as the lubricant flow rate is increased, the temperature difference becomes inconsequential. This can be attributed to the volume of oil entrapped in the bearing beyond that necessary for elastohydrodynamic lubrication (EHD). Initially, the smaller Hertzian contact ellipse with the hybrid ceramic bearing results in lower frictional losses. Churning of the oil at the higher flow rates accounts for the major frictional loss in the bearing resulting in both bearing types having similar temperature values.

In Pinel et al. (12) we reported the results of our research with high-speed, small-bore, angular-contact ball bearings run to 2.5 million $D N$ with both oil jet and under inner-ring lubrication. The results of this research optimized the design of oil-jet lubricated 35-mm-bore-angular-contact ball bearings to a single-outer-ring, land-guided cage with a $24^{\circ}$ contact angle with a relieved inner ring and a partially relieved outer ring. This design resulted in lower temperature and power loss.

The objectives of the work reported herein are to (1) extend our work with the 35-mm-bore-angular-contact ball bearings to include the effect of air-oil mist lubrication; (2) define and extend ball bearing operating limits with air-oil mist lubrication; and (3) compare air-oil mist lubricated angular-contact ball bearing operation with oil-jet lubricated bearings to $2.5 \times 10^{6} \mathrm{DN}$.

\section{APPARATUS, SPECIMENS, AND PROCEDURE}

\section{High-Speed Bearing Tester}

A schematic drawing of the air-turbine-driven test machine is shown in Fig. 1(a) and was initially described by Pinel and Signer (13). The test rig consisted of a horizontally mounted shaft supported by two preloaded, angular-contact ball bearings. The test bearing was overhung and mounted in a separate housing (Fig. 1(b)) that incorporated the hardware for lubrication, oil removal, thrust load application, and instru- 

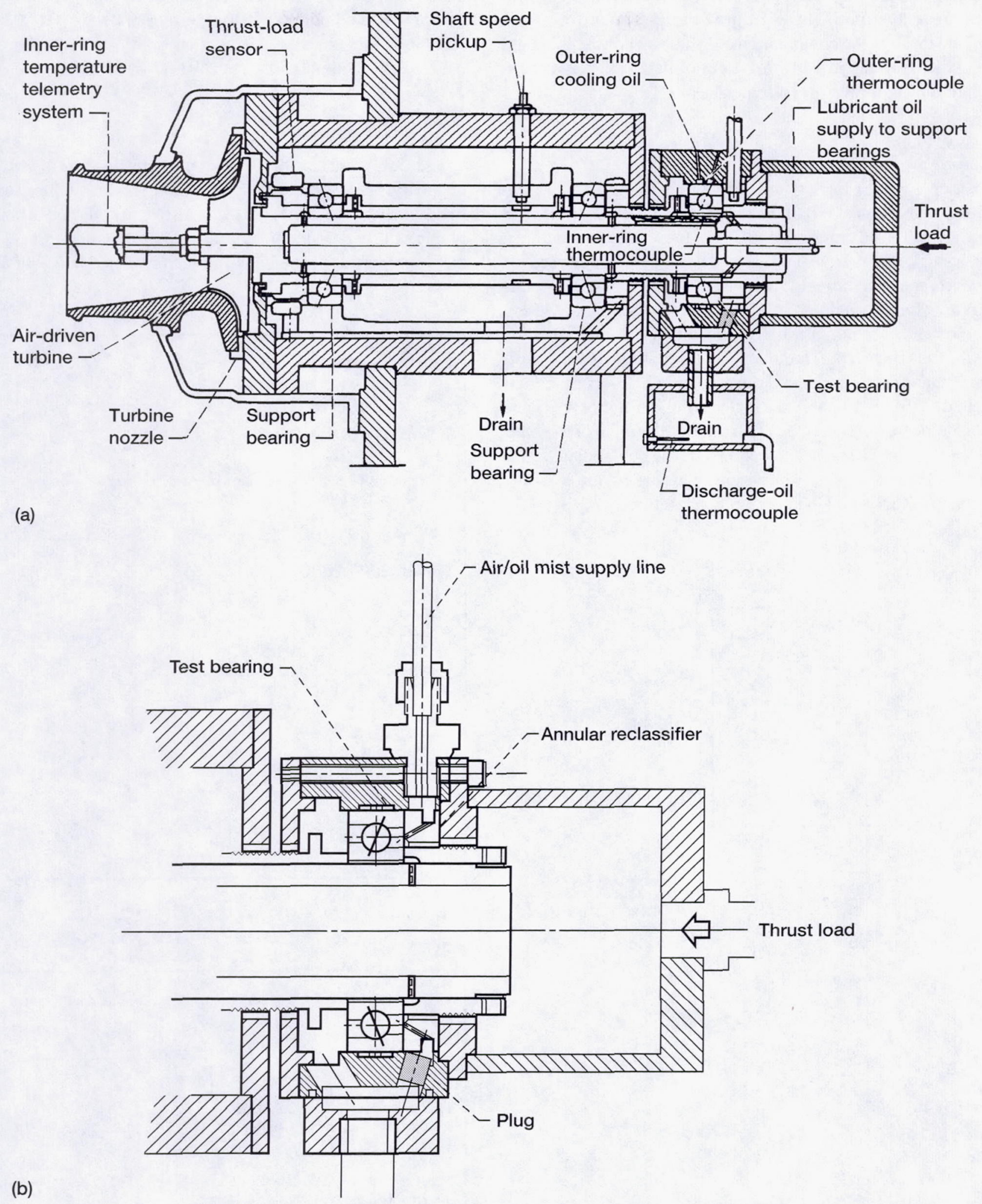

(b)

Figure 1.-High-speed, small-bore-bearing tester. (a) Schematic. (b) Test bearing installation. 
mentation for cage speed measurement. The test-bearing torque was measured with strain gages located near the end of an arm that prevented the housing from rotating. Thrust force was applied through the combination of a thrust needle bearing and a small roller support bearing to minimize test-housing restraint during torque measurements.

\section{Test Bearing}

Based upon the work reported in Pinel et al. (12), a 35-mmbore-angular-contact ball bearing with relieved inner and partially relieved outer rings, a $24^{\circ}$ unmounted contact angle, and a single-outer-ring, land-guided cage (Fig. 2) was used for the tests reported herein. The specifications for the test bearings are summarized in Table 1. The bearings were an ABEC 7 grade and each contained 16 balls with a nominal 7.14-mm (0.281-in.) diameter. The inner and outer rings and the balls were manufactured from consumable-electrode, vacuummelted, AISI M-50 steel. The surface finishes of the races were $0.125 \mu \mathrm{m}(5 \mu \mathrm{in}$.) rms or better. The surface finish of the balls was $0.025 \mu \mathrm{m}$ ( $1 \mu \mathrm{in}$.). The bearing surface composite finish was $0.130 \mu \mathrm{m}(5.1 \mu \mathrm{in}$.). The nominal hardness of the balls and rings was Rockwell $\mathrm{C} 62$ at room temperature.
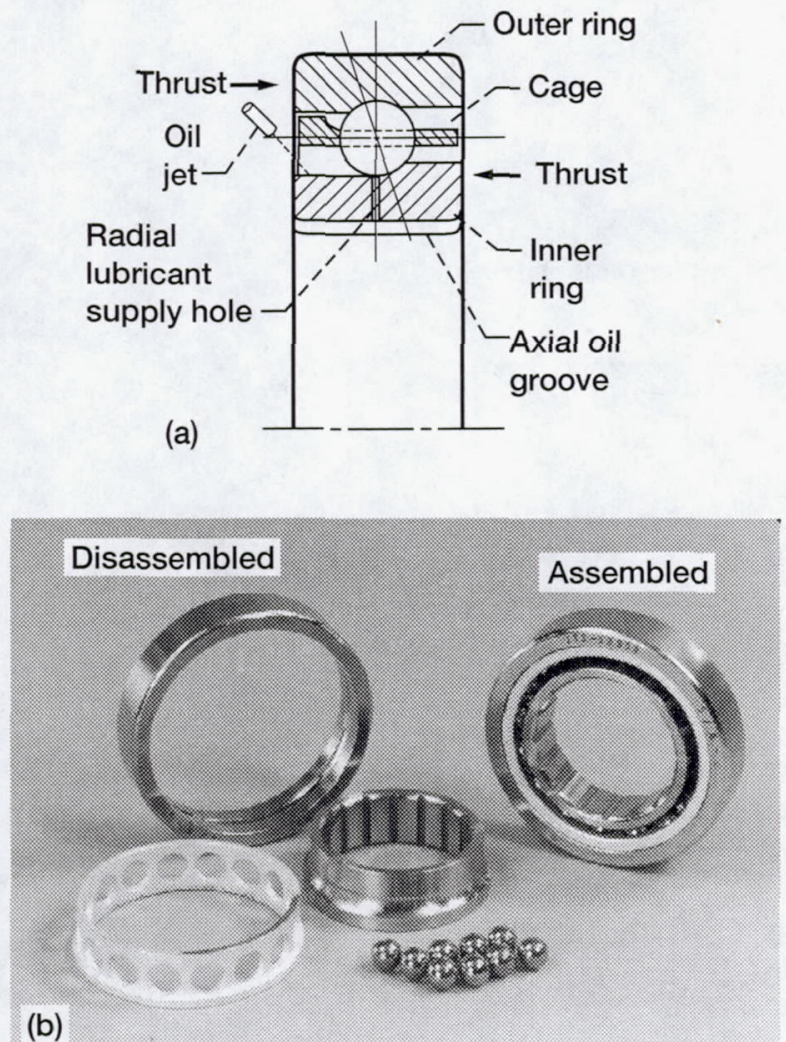

Figure 2.-35-mm-bore, angular-contact ball bearing with relieved inner ring (design 4). (a) Single outerring, land-guided cage. (b) Bearing assembly.
The cage was manufactured from AISI 4340 steel (AMS 6415) heat-treated to Rockwell C 28 to 36 hardness. It was completely coated with a 0.02 - to $0.04-\mathrm{mm}(0.0008$ - to 0.0015-in.) thickness of silver plate (AMS 2412). The cage balance was within $0.50 \mathrm{~g}-\mathrm{cm}\left(7 \times 10^{-3} \mathrm{oz}-\mathrm{in}\right.$. $)$.

\section{Lubricant}

The lubricant used for the parametric studies was a neopentylpolyol (tetra) ester. This Type II oil is qualified to the MIL-L-23699 specifications and also to the internal oil specifications of most major aircraft engine manufacturers. The major properties of the lubricant are presented in Table 2.

\section{TABLE 1.-TEST BEARING SPECIFICATIONS}

\begin{tabular}{|c|}
\hline Bearing \\
\hline Bore, $\mathrm{mm}$ (in.) .......................... \\
\hline 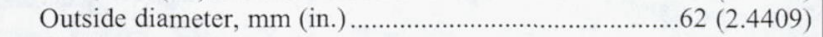 \\
\hline Width, mm (in.) \\
\hline Grade \\
\hline Surface composite finish, $\mu \mathrm{m}(\mu$ in.).................................... 0.130 (5.1) \\
\hline Cage \\
\hline Diametral land clearance, $\mathrm{mm}$ (in.) \\
\hline Outer-land-guided .......................... \\
\hline Inner-land-guided.............................. \\
\hline Diametral ball pocket clearance, $\mathrm{mm}$ (in.) …..................660 (0.026) \\
\hline Material ..............................AISI 4340 per AMS 6415 (silver plated) \\
\hline 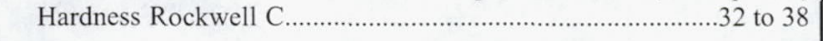 \\
\hline Balls \\
\hline Number............................................... \\
\hline Size (diam), mm (in.) ....................... \\
\hline Grade \\
\hline Material ................................................. AISI M-50 per AMS 6490 \\
\hline Hardness, Rockwell C (nominal)..........................................62 (min.) \\
\hline 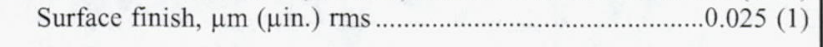 \\
\hline Race \\
\hline Conformity, percent \\
\hline Inner......................... \\
\hline Outer .......................... \\
\hline Surface finish, $\mu \mathrm{m}$ ( $\mu$ in. $)$, rms ...... \\
\hline Nominal contact angle, deg .............. \\
\hline Internal diametral clearance (IDC), $\mu \mathrm{m}$ ( $\mu$ in.) \\
\hline 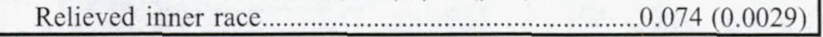 \\
\hline
\end{tabular}

TABLE 2.-PROPERTIES OF NEOPENTYLPOLYOL (TETRA) ESTER LUBRICANT

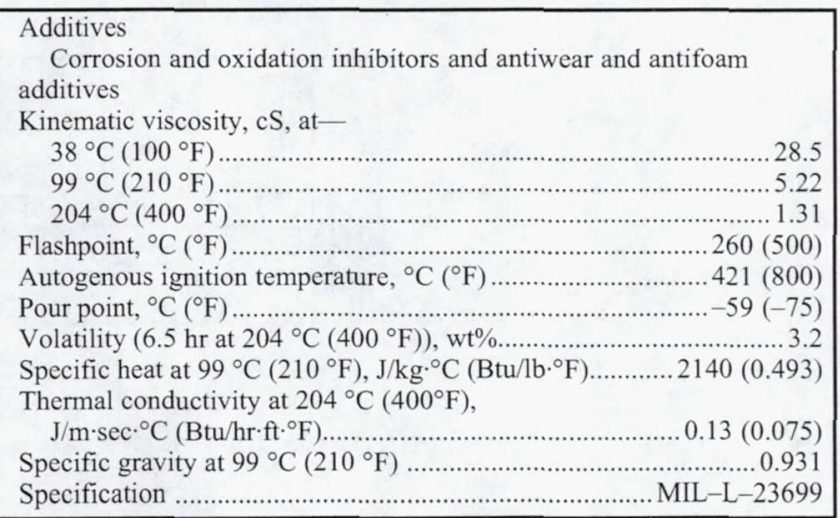




\section{Test Procedure}

After the test machine had been warmed by recirculating heated oil through the support bearings, the torque-measuring system was calibrated and a $667-\mathrm{N}(150-\mathrm{lbf})$ thrust load was applied to the test bearing. The shaft speed was then slowly brought up to a nominal speed of $28000 \mathrm{rpm}$. When the bearing and test machine temperatures stabilized (after 20 to $25 \mathrm{~min}$ ), the oil-inlet temperature and lubricant flow rate were set and the speed was increased to the desired value.

A nominal thrust load of $667 \mathrm{~N}$ (150 lbf) was used for these tests. For each condition, tests were run at nominal speeds of 30000,50000 , and $65000 \mathrm{rpm}$. A test series was run by starting at the lowest nominal speed, $30000 \mathrm{rpm}$, and progressing through 50000 , and $65000 \mathrm{rpm}$ before changing the lubricant flow rate. During testing, if it became apparent that the conditions would result in predictable distress of the test bearing or test rig or that the bearing temperature would exceed a predetermined temperature, the test point was aborted. Limiting ring temperature was set at $218^{\circ} \mathrm{C}\left(425^{\circ} \mathrm{F}\right)$ for the recirculating oil-jet lubrication. A higher ring temperature limit of $260^{\circ} \mathrm{C}\left(500^{\circ} \mathrm{F}\right)$ was chosen for air-oil mist lubrication, as some degradation of the lubricant was permissible for a "once through" lubrication system.

The shaft speed (inner-ring speed) was measured with a magnetic probe. The ball-pass frequency (cage speed) was measured with a semiconductor strain gage mounted in a cavity of the housing and was displayed on a spectrum analyzer.
Two thermocouples were assembled in the shaft so that the centrifugal force would push them against the test-bearing inner ring. Temperature readings were transmitted with a rotating telemetry system mounted on an auxiliary shaft at the air-turbine end of the test machine. Outer-ring temperatures were obtained by two thermocouples located $180^{\circ}$ from each other.

\section{Lubrication System}

Air-Oil Mist - A schematic diagram of the air-oil mist lubrication system used for these tests is shown in Fig. 3. The airoil mist system used was identical to that described by Schuller and Anderson (5). By flowing pressurized air into a venturi, the pressure in the venturi is reduced below that in the reservoir and oil is siphoned from the reservoir into the venturi. The oil in the venturi is atomized into a fine mist and carried into an annular reclassifier and into the bearing. Figure 1(b) shows the annular reclassifier and a cross section of the test bearing installation. The drain on the reclassifier side is plugged so as to force the air-oil mist through the reclassifier tubes and through the bearing.

The oil flow to the test bearing was regulated by air pressure to the lubrication tank and selection of the size of the capillary. The oil temperature was controlled by regulating the oil tank wall temperature. The average oil-in temperature was $49^{\circ} \mathrm{C}$ $\left(120^{\circ} \mathrm{F}\right)$ at the venturi entrance.

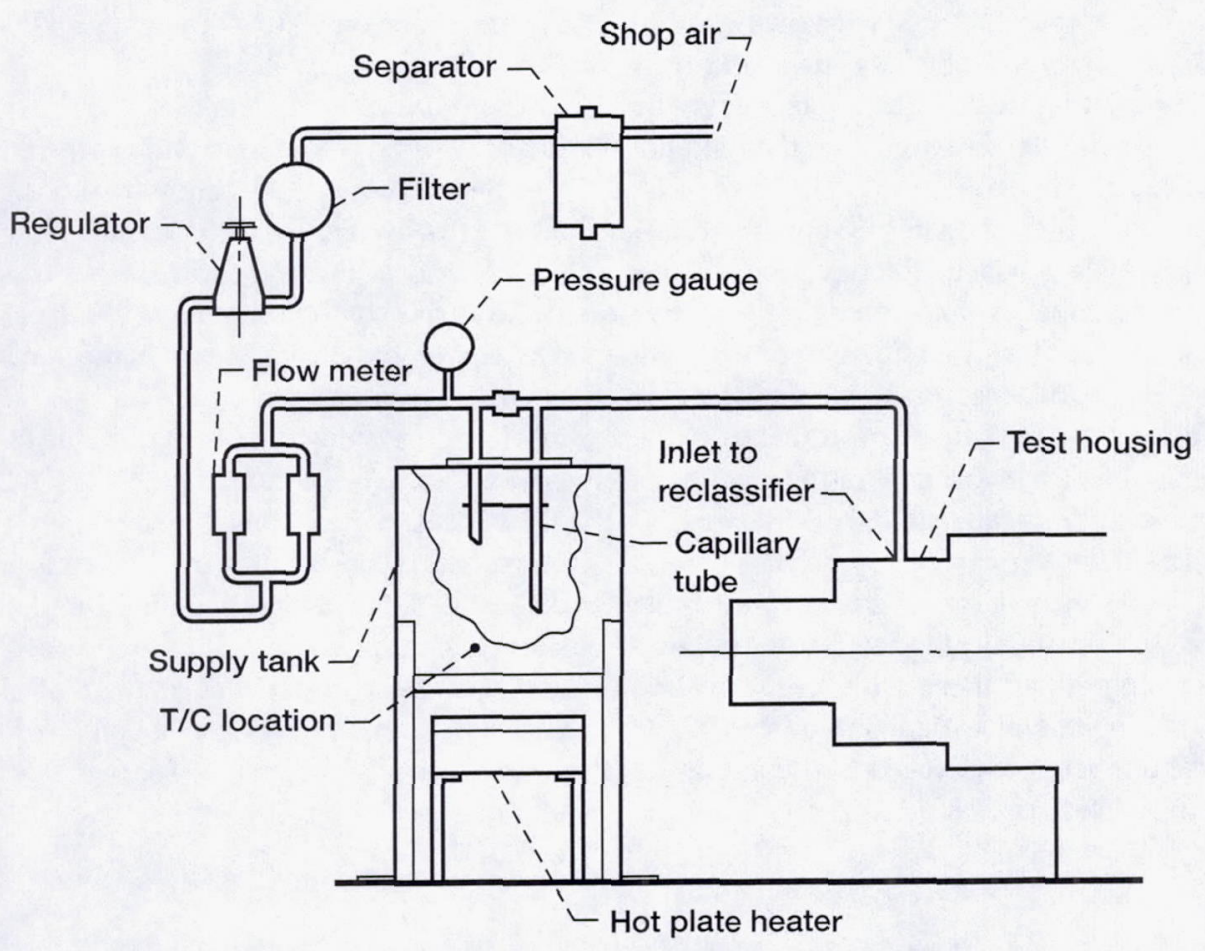

Figure 3.-Air-oil mist lubrication system. 
Oil Jet-For jet lubrication, the test bearing was lubricated by two jets on the nonloaded side of the inner ring. The jet outlets, located approximately $3 \mathrm{~mm}(0.12 \mathrm{in}$.) from the face of the bearing, were aimed at the inner raceway. In separate tests not reported herein, it was determined that a $20-\mathrm{m} / \mathrm{sec}$ $(66-\mathrm{ft} / \mathrm{sec})$ jet velocity provided the most efficient test bearing lubrication so this velocity was used in all the tests reported. The oil-in temperature measured just before the oil jet was $121^{\circ} \mathrm{C}\left(250^{\circ} \mathrm{F}\right)(12)$.

\section{RESULTS AND DISCUSSION}

\section{Effect of Lubricant Flow Rate}

Our experience with oil-jet lubrication has shown that the measured bearing temperature after the bearing reaches thermal equilibrium is a function of the bearing load, speed, oil-in temperature, oil-flow rate and volume of oil entrapped in the bearing. At thermal equilibrium, the bearing race temperatures without inner and/or outer ring cooling will always be higher than the oil-in temperature. As the oil-flow rate is increased, the bulk bearing temperature should approach the oil-in temperature. That is, the ring temperature minus the oil-in temperature should diminish up to the point where the heat generated due to power loss from increasing oil churning exceeds the convective cooling capacity of the oil. All oil-flow rates reported herein were kept well below this critical point.

In our experiments, we used two different oil-in temperatures, $49^{\circ} \mathrm{C}\left(120^{\circ} \mathrm{F}\right)$ and $121^{\circ} \mathrm{C}\left(250^{\circ} \mathrm{F}\right)$ for air-oil mist and oil-jet lubrication, respectively. These temperatures were selected as perhaps being representative of what may be used in high-speed turbomachinery applications. Thus, in our tests the temperature of the oil-jet lubricated bearing can never be less than $121^{\circ} \mathrm{C}\left(250^{\circ} \mathrm{F}\right)$. Similar experience or data did not exist for air-oil mist lubrication.

A comparison of the experimental results is shown in Fig. 4 for the test bearing for both the air-oil mist lubrication and oiljet lubrication. The measured inner- and outer-ring temperatures decreased as lubricant flow rate increased for both lubrication methods. Because the heat transfer to the lubricant is a function of the mass flow rate of the oil to bearing, the resultant bearing temperature at constant operating conditions is a function of the lubricant flow rate and the oil-in temperature independent of the oil delivery system.

Referring to Fig. 4(a), because of the lower flow rate to the bearing at $65000 \mathrm{rpm}$ with air-oil mist lubrication, the bearing ring temperatures are higher than those with jet lubrication even though the oil-in temperature with air-oil mist is $72{ }^{\circ} \mathrm{C}$ $\left(130^{\circ} \mathrm{F}\right)$ lower. These temperatures exceed our temperature limitation for oil-jet lubrication of $218^{\circ} \mathrm{C}\left(425^{\circ} \mathrm{F}\right)$.
Bearing temperatures of approximately $190{ }^{\circ} \mathrm{C}\left(374^{\circ} \mathrm{F}\right)$ at $50000 \mathrm{rpm}$ with air-oil mist flow rates between 0.02 and $0.04 \mathrm{\ell} / \mathrm{min}$ are equivalent to those temperatures with an oil-jet flow rate of $0.08 \mathrm{\ell} / \mathrm{min}$. At $0.04 \mathrm{\ell} / \mathrm{min}$, the bearing temperature at a speed of $30000 \mathrm{rpm}$ is approximately the same as with that obtained with jet lubrication at $2 \mathrm{l} / \mathrm{min}$.

Referring to Fig. 4(b), the difference between ring temperature and oil-in temperature is shown as a function of lubricant flow rate. These are the same data as those of Fig. 4(a) but independent of oil-in temperature. As previously discussed, bearing temperature is an inverse function of lubricant flow rate and independent of the lubricant delivery system. It can be reasonably concluded that a specified bearing temperature can be maintained with less oil flow using air-oil mist providing the oil-in temperature is kept low. However, at the higher speed of $65000 \mathrm{rpm}\left(2.3 \times 10^{6} \mathrm{DN}\right)$, the air-oil mist lubrication system becomes marginally effective to maintain bearing temperature. This necessitates the need to use either oil-jet lubrication or under-ring lubrication (Pinel et al. (12)).

For air-oil mist lubrication, the inner-ring temperature is higher than that of the outer ring. This difference in temperature between the inner and outer rings was nominally less than $12^{\circ} \mathrm{C}\left(22^{\circ} \mathrm{F}\right)$. Higher heat generation would be expected at the ball inner-race Hertzian contact because of the contact kinematics.

For oil-jet lubrication, the outer-ring temperature is higher than the inner-ring temperature. The same relation was reported in Pinel et al. (12) for under-ring lubrication. At a flow rate of $0.09 \mathrm{\ell} / \mathrm{min}$ at $50000 \mathrm{rpm}$, the outer-ring temperature is less than $18^{\circ} \mathrm{C}\left(32^{\circ} \mathrm{F}\right)$ higher than that of the inner ring. As lubricant flow rate is increased the temperature decreases and the inner- and outer-ring temperatures become nearly equal as shown in Fig. 4(a).

The lubricant jets were aimed directly at the bearing inner raceway surface. The lower inner-ring temperatures for the jet and the inner-ring lubrication methods may be explained by more effective convective cooling.

Referring to Fig. 5, bearing power loss as a function of oilflow rate is shown for both air-oil mist and oil-jet lubrication. The power loss data is based on mechanical measurements of bearing torque. Because of low oil flow with the air-oil mist lubrication system, it was not possible to thermally determine power loss. We reported in Pinel et al. (12) that because of the differences in measurement techniques, the thermal measurements were consistently $0.2 \mathrm{~kW}(0.3 \mathrm{hp})$ higher than those determined mechanically with oil-jet lubrication. These data show that the power loss is a function of oil flow to the bearing and, for these tests, independent of the delivery system. Because a smaller oil flow is delivered with the air-oil mist system, the power loss is lower than that obtained with oil-jet lubrication. 

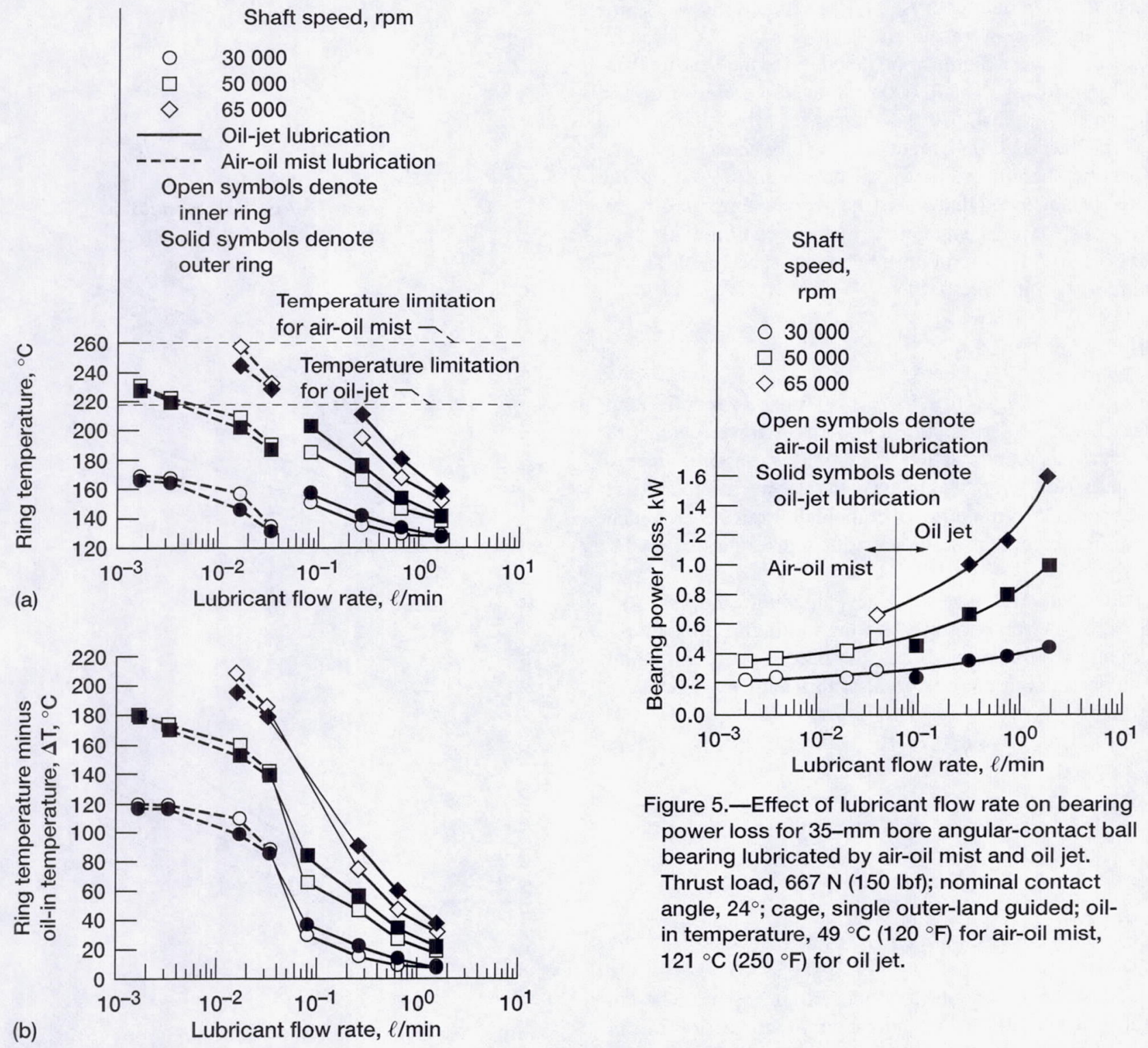

Figure 4.-Effect of lubricant flow rate on bearing temperature for 35-mm bore angular-contact ball bearing lubricated by air-oil mist and oil jet. Thrust load, $667 \mathrm{~N}$ (150 lbf); nominal contact angle, 24; cage, single outer-land guided; oil-in temperature, $49^{\circ} \mathrm{C}\left(120^{\circ} \mathrm{F}\right)$ for air-oil mist, $121^{\circ} \mathrm{C}\left(250^{\circ} \mathrm{F}\right)$ for oil jet. (a) Measured ring temperatures. (b) Difference between ring temperature and oil-in temperature.

Figure 5.-Effect of lubricant flow rate on bearing power loss for 35- $\mathrm{mm}$ bore angular-contact ball bearing lubricated by air-oil mist and oil jet. Thrust load, $667 \mathrm{~N}$ (150 lbf); nominal contact angle, $24^{\circ}$; cage, single outer-land guided; oilin temperature, $49^{\circ} \mathrm{C}\left(120^{\circ} \mathrm{F}\right)$ for air-oil mist, $121^{\circ} \mathrm{C}\left(250^{\circ} \mathrm{F}\right)$ for oil jet. 


\section{Effect of Speed}

Figure 6 shows the effect of speed on bearing temperature and power loss. For a given oil-flow rate, bearing temperature and power loss increase with increases in speed, independent of the lubrication delivery system. Referring to Fig. 4(a), airoil mist lubrication results in high-bearing temperature because of a lower volume of oil delivered to the bearing than with oil jet. However, at $50000 \mathrm{rpm}$, the lower power loss is approximately a third of that obtained for oil-jet lubrication and, from Pinel et al. (12), for under-ring lubrication. From the data reported herein and those of Rosenlieb $(9,10)$, it can be reasonably concluded that where the bearing temperature rise is solely caused from heat internally generated from within the bearing cavity, the maximum obtainable speed with air-oil mist lubrication is $2.5 \times 10^{6} \mathrm{DN}$.

\section{Minimum Oil Flow}

Referring to Fig. 4(a), for air-oil mist lubrication, at $2.3 \times 10^{6} \mathrm{DN}(65000 \mathrm{rpm})$, the minimum oil flow necessary to maintain a temperature of $260^{\circ} \mathrm{C}\left(500^{\circ} \mathrm{F}\right)$ was approximately $0.02 \mathrm{\ell} / \mathrm{min}$. No attempt was made in these tests to determine at the other speeds a minimum or threshold flow rate below which the bearing temperature would exceed a temperature of $260^{\circ} \mathrm{C}$ $\left(500^{\circ} \mathrm{F}\right)$.

Schuller and Anderson $(5,6)$ developed an empirical formula which we reconstituted relating minimum oil-flow requirements as a function of load and speed for successful ball bearing operation for an air-oil mist lubrication system where

$$
V \approx k\left[P^{4.22} \times 10^{1.18(S-8)}\right]
$$

Where
$\begin{array}{ll}V & \text { oil-flow rate, } \ell / \mathrm{min} \\ k & \text { proportionality factor } \\ P & \text { thrust load, } \mathrm{N} \\ S & D N \text { value } \times 10^{-5}\end{array}$

Equation (1) was calibrated by us at $2.3 \times 10^{6} \mathrm{DN}$ $(65000 \mathrm{rpm})$ and a flow rate $(V)$ of $0.038 \mathrm{\ell} / \mathrm{min}$ with the 35 -mm-bore-angular-contact ball bearings reported herein whereby $k=9.16 \times 10^{-32}$. A resultant minimum oil-flow rate at of $17.4 \times 10^{-18} \mathrm{\ell} / \mathrm{min}$ at 1 million $D N$ is predicted using Eq. (1). This predicted oil-flow rate is significantly lower than the rate we used and experimentally determined by Schuller and Anderson $(5,6)$ under comparable conditions. The relation in the brackets relating load, $P$, and speed, $S$, appears to us to be specific to the data of Schuller and Anderson (5) and does not appear to be universally applicable for predicting minimum oil flow with air-oil mist lubrication.
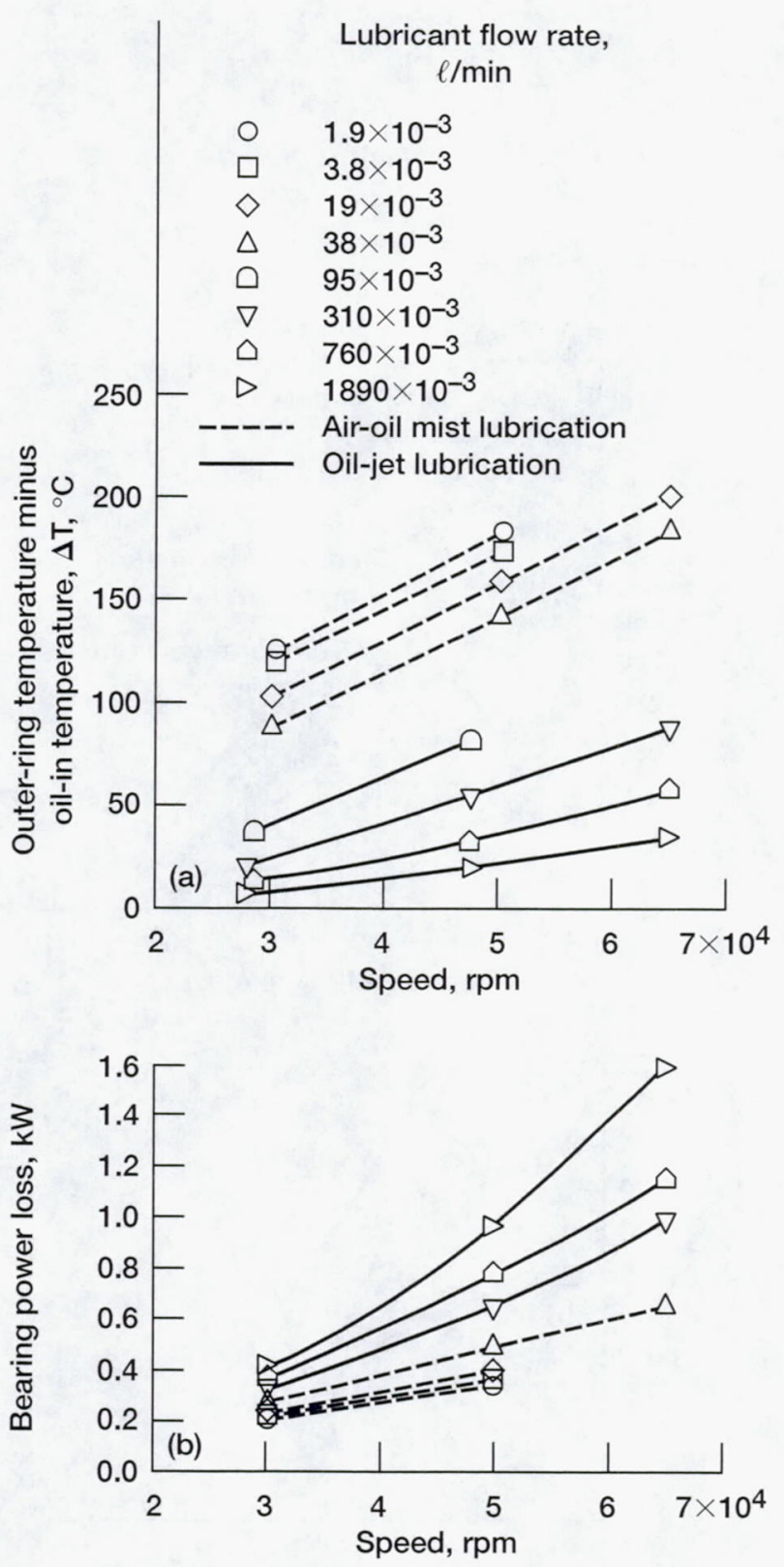

Figure 6.-Effect of bearing speed on bearing temperature and power loss for 35- $\mathrm{mm}$ bore angular-contact ball bearing lubricated by air-oil mist and oil jet. Thrust load, $667 \mathrm{~N}$ (150 lbf); nominal contact, $24^{\circ}$; cage, single outer-land guided; oil-in temperature, $49^{\circ} \mathrm{C}\left(120^{\circ} \mathrm{F}\right)$ for air-oil mist, $121^{\circ} \mathrm{C}$ $\left(250^{\circ} \mathrm{F}\right)$ for oil jet. (a) difference between outer-ring temperature and oil-in temperature. (b) Bearing power loss. 


\section{Effect on Cage Speed}

The cage (separator) epicyclic speed ratio for the angularcontact ball bearings changes with speed, load, and temperature. The difference between the cage epicyclic speed and the measured cage speed is indicative of ball slip as follows:

Percent Cage Slip $=[1-($ Measured Cage Speed $\div$ Calculated Epicyclic Cage Speed) $] \times 100$

Cage slip is a function of the traction in the ball-race contact and the resistance to rolling within the bearing. Experience has shown that both ball and roller bearings can tolerate reasonable amounts of rolling element to raceway slip provided that a sufficient EHD film is maintained in the ball-race contact. However, under marginal lubrication conditions, such slip can result in bearing damage and failure.

For the bearing used in this study, under a thrust load of $667 \mathrm{~N}(150 \mathrm{lbs})$ and speeds of 30000,50000 , and $65000 \mathrm{rpm}$, the epicyclic cage speeds were calculated to be 13600,24000 , and $33100 \mathrm{rpm}$, respectively. Based upon measured cage speed, the percentage of cage slip was calculated and plotted as a function of bearing speed for air-oil mist lubrication and oil-jet lubrication in Fig. 7. Cage slip increased with increases in speed. Values of cage slip as high as 7 percent were measured. There was no damage to the bearing surfaces as the result of cage slip. Contrary to what we expected, cage slip was generally higher with air-oil mist lubrication than with oil-jet lubrication.

\section{Effect on Bearing Fatigue Life}

We calculated the fatigue life as a function of speed based on measured ring temperature with oil-jet lubrication and underring lubrication for the 35-mm-bore-angular-contact ball bearing used in this study. We reported and discussed the results in Pinel et al. (12). As is commonly expected, life decreased both in total revolutions to failure and in absolute hours as a function of speed.

Shamim and Kettleborough $(4,8)$ reported on endurance tests with air-oil mist lubrication and industrial sump lubrication systems. They reported that the air-oil mist lubricated bearings ran approximately $10^{\circ} \mathrm{C}\left(18^{\circ} \mathrm{F}\right)$ cooler than those with sump lubrication and with a 25 -percent reduction in power loss. They ran endurance tests with 60 -mm-bore-angular-contact ball bearings at $2400 \mathrm{rpm}(144000 \mathrm{DN})$ and a thrust load of $18900 \mathrm{~N}$ (4250 lbs) using an air-oil mist lubrication system and a synthetic ISO Grade 68 oil. They compared their results with those calculated for the same bearing using an oil sump lubrication system with a mineral oil base lubricant. They concluded that longer life is obtained with air-oil mist lubrication with the synthetic lubricant than with the same bearings operated with the mineral oil and a sump lubrication system.

For a given bearing load and speed, the bearing life is affected by the internal diametral clearance at operating temperature and the EHD film thickness. The method of lubrication used can and apparently does affect these parameters. Thus, while the Shamim and Kettleborough $(4,8)$ conclusion is correct for their experimental conditions and assumptions made for their calculations, it may not always be correct for other bearing operating conditions.

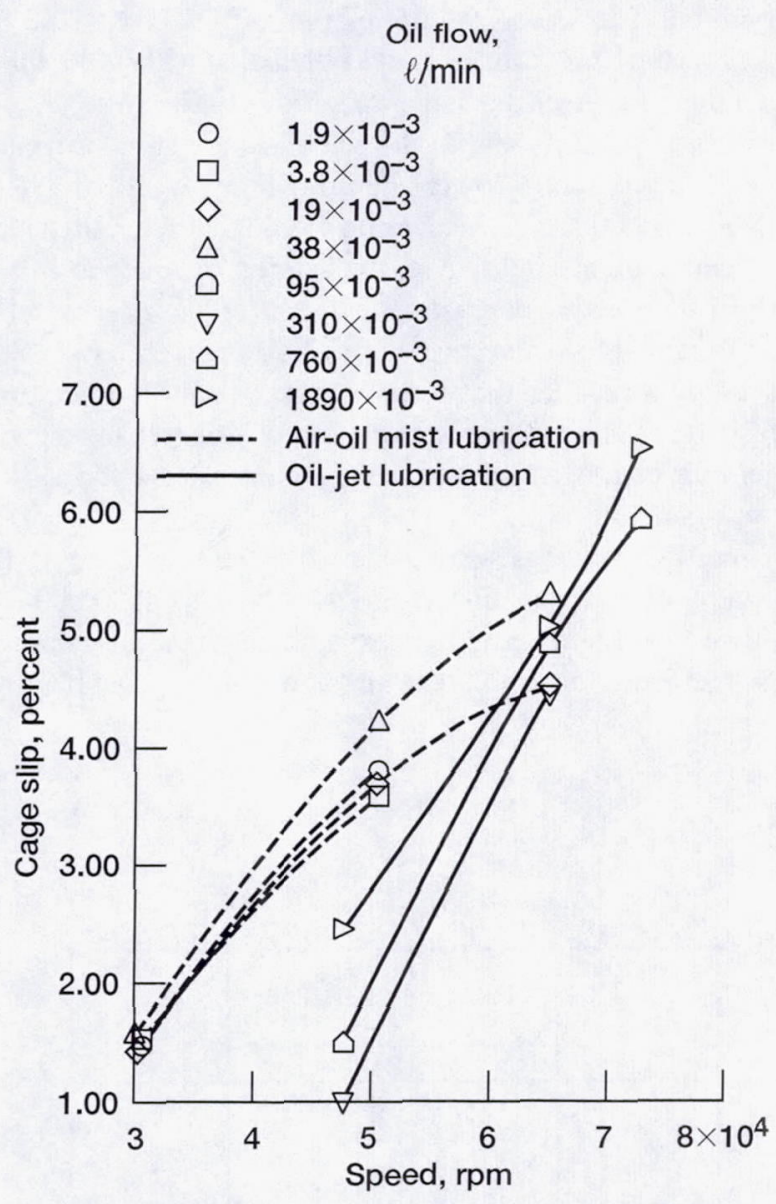

Figure 7.-Effect of lubrication means and speed on cage slip for 35- $\mathrm{mm}$ bore, angular-contact ball bearing lubricated by air-oil mist and oil jet. Thrust load, $667 \mathrm{~N}$ (150 lbf); nominal contact angle, 24; cage, single outer-land guided; oil-in temperature, $49^{\circ} \mathrm{C}\left(120^{\circ} \mathrm{F}\right)$ for air-oil mist, $121^{\circ} \mathrm{C}\left(250^{\circ} \mathrm{F}\right)$ for oil jet. 
Based upon oil-in temperature and lubricant flow rate, bearing temperature can to some reasonable degree of engineering certainty be controlled. Bearing life will be a function of the resulting bearing temperature and the difference in temperature between the inner and outer rings. We calculated bearing lives at three speeds, 30000,50000 , and $65000 \mathrm{rpm}$ and four hypothetical temperature combinations. These inner-ring and outer-ring temperature combinations were 154 and $143^{\circ} \mathrm{C}\left(310\right.$ and $\left.290^{\circ} \mathrm{F}\right) ; 149$ and $149^{\circ} \mathrm{C}(300$ and 3 $\left.00^{\circ} \mathrm{F}\right) ; 143$ and $154^{\circ} \mathrm{C}\left(290\right.$ and $\left.310^{\circ} \mathrm{F}\right)$ and 138 and $138^{\circ} \mathrm{C}$ $\left(280\right.$ and $\left.280^{\circ} \mathrm{F}\right)$. The hotter inner-ring temperature represents what might be obtained with air-oil mist lubrication while the hotter outer-ring temperature is more representative of our results with oil-jet lubrication. The assumption of both rings being of equal temperature can occur with both methods of lubrication. The lower ring temperature of $138^{\circ} \mathrm{C}\left(280^{\circ} \mathrm{F}\right)$ represents the lower temperatures obtainable with either lubrication method under the same operating conditions.

The results of the bearing life analysis are summarized in Table 3. Based upon a lower operating temperature of $138^{\circ} \mathrm{C}$ $\left(280^{\circ} \mathrm{F}\right)$ at $30000 \mathrm{rpm}$, the bearing would theoretically have a 56 percent increase in life over the bearing operated at $149^{\circ} \mathrm{C}$ $\left(300^{\circ} \mathrm{F}\right)$. As speed is increased, the life differences decrease. At $65000 \mathrm{rpm}$, the difference in life is 9 percent. It can be reasonably concluded that because gross bearing temperatures with air-oil mist lubrication are generally higher than that with oil-jet lubrication, a lower bearing life may occur for a given operating condition.

Where the bearings were assumed to be nominally at the same temperature, the oil-jet lubricated bearing at $30000 \mathrm{rpm}$ having a lower inner-ring temperature, can have a theoretical life 47 percent greater than the air-oil mist lubricated bearing.

TABLE 3.-THEORETICAL EFFECT OF BEARING COMPONENT TEMPERATURE ON LIFE OF 35-mm BORE ANGULAR-CONTACT BALL BEARING. THRUST LOAD, $667 \mathrm{~N}$ (150 lbf); NOMINAL CONTACT ANGLE, $24^{\circ}$; CAGE, SINGLE OUTER-LAND GUIDED

\begin{tabular}{|c|l|l|c|}
\hline $\begin{array}{c}\text { Inner-ring } \\
\text { speed, } \\
\text { rpm }\end{array}$ & \multicolumn{2}{|c|}{$\begin{array}{c}\text { Assumed ring } \\
\text { temperature } \\
{ }^{\circ} \mathrm{C}\left({ }^{\circ} \mathrm{F}\right)\end{array}$} & \multirow{2}{*}{$\begin{array}{c}\text { Bearing } \\
\text { life, } \\
\text { hrs }^{\mathrm{a}}\end{array}$} \\
\cline { 2 - 3 } & Inner ring & Outer ring & \\
\hline 30000 & $138(280)$ & $138(280)$ & 2049 \\
& $149(300)$ & $149(300)$ & 1315 \\
& $143(290)$ & $154(310)$ & 1576 \\
& $154(310)$ & $143(290)$ & 1072 \\
\hline 50000 & $138(280)$ & $138(280)$ & 899 \\
& $149(300)$ & $149(300)$ & 735 \\
& $143(290)$ & $154(310)$ & 721 \\
& $154(310)$ & $143(290)$ & 703 \\
\hline 65000 & $138(280)$ & $138(280)$ & 274 \\
& $149(300)$ & $149(300)$ & 251 \\
& $143(290)$ & $154(310)$ & 249 \\
& $154(310)$ & $143(290)$ & 246 \\
\hline
\end{tabular}

Life factor for effect of elastohydrodynamic film thickness included. No other life factors included.
At 50000 and $60000 \mathrm{rpm}$, the life differences are insignificant. From this analysis and the measured temperatures, it may be assumed that where higher bearing temperatures occur with air-oil mist lubrication, lower bearing life will result.

\section{GENERAL COMMENTS}

According to Bloch and Shamim (4), air-oil mist lubrication systems have been in use since the 1930's. They describe the state-of the-art of air-oil mist lubrication systems and discuss their applications. The economics for using air-oil mist is compelling based upon acquisition and operating costs as well as simplicity of design. However, the operating speeds for which they reported rolling-element bearing operating data were relatively low, around $200000 \mathrm{DN}$. The air-oil mist lubrication bearing data reported by Schuller and Anderson (5) was up to $1.2 \times 10^{6} \mathrm{DN}$. The work reported by Rosenlieb $(9,10)$ extended rolling-element bearing operating speed with air-oil mist lubrication to $2.5 \times 10^{6} \mathrm{DN}$.

The data reported herein for both air-oil mist lubrication and oil-jet lubrication were for bearing operation where the bearing temperature and power loss were caused from frictional heat generation internal to the bearing. It cannot be assumed a priori that a specific lubrication system will result in lower or higher bearing temperatures, power loss, and higher or lower lives than other lubrication systems. The total thermal environment of the bearing must be considered. As an example, if there is an external heat source such as a hot section of a turbine engine, an air-oil mist lubrication system may not have sufficient heat transfer capacity to maintain the required operating temperature for the bearing. A thermal and heat transfer analysis as well as a bearing fit-up study needs to be undertaken before a commitment is made to a specific lubrication system.

Another issue that must be considered is the EHD film thickness in the ball-race contact. If the calculated lives of Table 3 were extrapolated to $10000 \mathrm{rpm}$ without further calculation of film thickness, it would be concluded that the life of the bearing would be $3100 \mathrm{hr}$ air-oil mist lubrication and $1500 \mathrm{hr}$ oil-jet lubrication. However, at $10000 \mathrm{rpm}$ and temperature of 138 and $149^{\circ} \mathrm{C}\left(280\right.$ and $\left.300^{\circ} \mathrm{F}\right)$, the EHD film thickness is sufficiently low wherein the bearing operates in the boundary lubrication regime. Accordingly, the calculated bearing lives for both lubrication systems are the same, $1493 \mathrm{hr}$. The effects of lubricant additives, which are known to affect bearing life, were not addressed in this program.

For high-speed turbomachinery applications an issue of stray (oil) mist must be addressed. As described by Bloch and Shamim (4), as oil mist passes through the bearing, larger oil particles are deposited on the bearing surfaces. However, smaller particles of oil go out with the air. These smaller particles are called stray mist. Bloch and Shamim (4) report that 40 to 60 percent of the oil may go out as stray mist. 
They discuss closed loop air-oil mist lubrication systems that can capture or recycle stray mist. The ability to capture or recycle spray mist may be a condition precedent to the application of air-oil mist lubrication systems to high-speed turbomachinery. An alternate approach for air-breathing turbine engines is to burn the stray oil mist with the fuel.

\section{SUMMARY OF RESULTS}

Parametric tests were conducted with an optimized 35-mm-bore-angular-contact ball bearing on a high-speed, high-temperature bearing tester. The test bearing has a singleouter-ring, land-guided cage with a nominal $24^{\circ}$ contact angle. Both air-oil mist lubrication and oil-jet lubrication systems were used and compared to speeds of $2.5 \times 10^{6} \mathrm{DN}$. The oil-in temperatures were $49^{\circ} \mathrm{C}\left(120^{\circ} \mathrm{F}\right)$ and $121^{\circ} \mathrm{C}\left(250^{\circ} \mathrm{F}\right)$, for airoil mist and oil-jet lubrication, respectively. The lubricant was a neopentylpolyol (tetra) ester that met the MIL-L-23699 specification. The following results were obtained:

1. Where the bearing temperature rise is solely caused from heat internally generated from within the bearing cavity, the maximum obtainable speed with air-oil mist lubrication is $2.5 \times 10^{6} \mathrm{DN}$.

2. Lower bearing temperatures and higher power losses are obtained with oil-jet lubrication than with air-oil mist lubrication.

3. Bearing power loss is a direct function of oil flow to the bearing and independent of delivery system. For a given oil-flow rate, bearing temperature and power loss increase with increases in speed.

4. Bearing life is an inverse function of temperature, the difference in temperature between the individual bearing ring components, and the resultant elastohydrodynamic (EHD) film thicknesses. Bearing life is independent of the oil delivery system except as it affects these temperatures.

5. Cage slip increased with increases in speed. Cage slip as high as 7 percent was measured and was generally higher with air-oil mist lubrication than with oil-jet lubrication.

\section{REFERENCES}

1. Zaretsky, E.V., "Rolling Bearing and Gear Lubrication," Tribology for Aerospace Applications, E. V. Zaretsky, ed., STLE SP-37, Society of Tribologists and Lubrication Engineers, Park Ridge, IL, pp. 207-323, (1997).
2. Zaretsky, E.V., Signer, H., and Bamberger, E.N., "Operating Characteristics of $120 \mathrm{~mm}$ Bore Ball Bearings at $3 \times 10^{6}$ DN," NASA TN D-7837, (1974).

3. Signer, H., Bamberger, E.N., and Zaretsky, E.V., "Parametric Study of the Lubrication of Thrust Loaded $120 \mathrm{~mm}$ Bore Ball Bearings to 3 Million DN," ASME Jour. Lubr. Tech., 96, 3, pp. 515-525, (1974).

4. Bloch, H.P., and Shamim, A., Oil Mist Lubrication: Practical Applications, Prentice Hall, (1998).

5. Schuller, F.T., and Anderson, W.J., "Operating Characteristics of 75-Millimeter Bore Ball Bearings at Minimum Oil Flow Rates Over a Temperature Range to $500^{\circ} \mathrm{F}$," STLE Lubr. Engr., 17, 4, pp. 291 -298, (1961).

6. Anderson, W.J., "Extreme-Temperature Bearings, " Advanced Bearing Technology, E.E. Bisson and W.J. Anderson, eds., National Aeronautics and Space Administration, Washington, DC, NASA SP-38, pp. 309-370, (1964).

7. Morrison, F.R., Zielinski, J., and James, R., "Effects of Synthetic Industrial Fluids on Ball Bearing Performance," ASME Jour. Energy Source Tech., 104, 1, pp. 174-181, (1982).

8. Shamim, A., and Kettleborough, C.F., "Tribological Performance Evaluation of Oil Mist Lubrication," ASME Jour. Energy Source Tech., 116, 1, pp. 224-231, (1994).

9. Rosenlieb, J.W., "Microfog Lubrication for Aircraft Engine Bearings," SKF- AL75TO32 (NASA CR-134977), SKF Industries, Inc., King of Prussia, PA, (1976).

10. Rosenlieb, J.W., "Emergency and Microfog Lubrication and Cooling of Bearings for Army Helicopters," SKFAL77TO21 (NASA CR-135195), SKF Industries, Inc., King of Prussia, PA, (1978).

11. Jeng, Y.R., and Huang, P.Y., "Temperature Rise of Hybrid Ceramic and Steel Ball Bearings with Oil-Mist Lubrication," STLE Lubr. Engr., 56, 12, pp. 18-23, (2000).

12. Pinel, S.I., Signer, H.R., and Zaretsky, E.V., "Design and Operating Characteristics of High-Speed, Small-Bore, Angular-Contact Ball Bearings," STLE Trib. Trans., 41, 4, pp. 423-434, (1998).

13. Pinel, S.I., and Signer, H.R., "Development of a HighSpeed, Small Bore Bearing Test Machine," NASA CR-135083, (1976). 
Public reporting burden for this collection of information is estimated to average 1 hour per response, including the time for reviewing instructions, searching existing data sources, gathering and maintaining the data needed, and completing and reviewing the collection of information. Send comments regarding this burden estimate or any other aspect of this collection of information, including suggestions for reducing this burden, to Washington Headquarters Services, Directorate for information Operations and Reports, 1215 Jefferson Davis Highway, Suite 1204, Arlington, VA 22202-4302, and to the Office of Management and Budget, Paperwork Reduction Project (0704-0188), Washington, DC 20503.

\begin{tabular}{|l|l|l|}
\hline 1. AGENCY USE ONLY (Leave blank) & 2. REPORT DATE & 3. REPORT TYPE AND DATES COVERED
\end{tabular}

\begin{tabular}{|l|l|l} 
& August 2001 & Technical Memorandum \\
\hline
\end{tabular}

Comparison Between Oil-Mist and Oil-Jet Lubrication of High-Speed, Small-Bore, Angular-Contact Ball Bearings

5. FUNDING NUMBERS

6. AUTHOR(S)

WU-253-02-98-00

Stanley I. Pinel, Hans R. Signer, and Erwin V. Zaretsky

7. PERFORMING ORGANIZATION NAME(S) AND ADDRESS(ES)

National Aeronautics and Space Administration

John H. Glenn Research Center at Lewis Field

Cleveland, Ohio 44135-3191

9. SPONSORING/MONITORING AGENCY NAME(S) AND ADDRESS(ES)

National Aeronautics and Space Administration

Washington, DC 20546-0001
8. PERFORMING ORGANIZATION REPORT NUMBER

E-12458

11. SUPPLEMENTARY NOTES

Prepared for the 56th Annual Meeting sponsored by The Society of Tribologists and Lubrication Engineers, Orlando, Florida, May 20-24, 2001. Stanley I. Pinel, Pinel Engineering, Fullerton, California; Hans R. Signer, Signer Technical Services, Fullerton, California; Erwin V. Zaretsky, NASA Glenn Research Center. Responsible person, Erwin V. Zaretsky, organization code 5900, 216-433-3241

12a. DISTRIBUTION/AVAILABILITY STATEMENT

12b. DISTRIBUTION CODE

Unclassified - Unlimited

Subject Category: 37

Distribution: Nonstandard

Available electronically at http://gltrs.grc.nasa.gov/GLTRS

This publication is available from the NASA Center for AeroSpace Information, 301-621-0390.

13. ABSTRACT (Maximum 200 words)

Parametric tests were conducted with an optimized 35-mm-bore-angular-contact ball bearing on a high-speed, hightemperature bearing tester. Results from both air-oil mist lubrication and oil-jet lubrication systems used to lubricate the bearing were compared to speeds of $2.5 \times 10^{6} \mathrm{DN}$. The maximum obtainable speed with air-oil mist lubrication is $2.5 \times 10^{6} \mathrm{DN}$. Lower bearing temperatures and higher power losses are obtained with oil-jet lubrication than with air-oil mist lubrication. Bearing power loss is a direct function of oil flow to the bearing and independent of oil delivery system. For a given oil-flow rate, bearing temperature and power loss increase with increases in speed. Bearing life is an inverse function of temperature, the difference in temperature between the individual bearing ring components, and the resultant elastohydrodynamic (EHD) film thicknesses. Bearing life is independent of the oil delivery system except as it affects temperature. Cage slip increased with increases in speed. Cage slip as high as 7 percent was measured and was generally higher with air-oil mist lubrication than with oil-jet lubrication.

\section{SUBJECT TERMS}

Rolling-element bearings; Ball bearings; Life prediction; Lubrication; Oil-jet lubrication; Air-oil mist lubrication

\begin{tabular}{|l|l} 
17. SECURITY CLASSIFICATION & 18. SECURITY CLASSIFICATION
\end{tabular} OF REPORT OF THIS PAGE

Unclassified

Unclassified

19. SECURITY CLASSIFICATION OF ABSTRACT

Unclassified 